\title{
Cadernos de Saúde Pública: Rumo ao ano 2000
}

Com este fascículo, Cadernos de Saúde Pública (CSP) completa 15 anos de publicação, razão para comemorar com todos aqueles que, ao longo desses anos, têm participado desse projeto - autores, leitores e consultores, dentre outros. De nossa parte, esse marco é, sem dúvida, motivo de grande contentamento. Vemos também o 15o aniversário de CSP como um momento oportuno de pausa para reavaliação e planejamento para o futuro. Estamos cientes dos muitos desafios a serem enfrentados na busca de uma revista cientificamente consistente, de alta qualidade editorial, ágil e de circulação cada vez mais ampla.

Alicerçado na tradição de pesquisa instalada em Manguinhos cem anos atrás, por ocasião da criação do Instituto Oswaldo Cruz, CSP consolidou-se como espaço privilegiado para o registro e a disseminação da pesquisa de ponta em saúde pública no Brasil e na América Latina, assim como em outras regiões do mundo onde a saúde pública figura na pauta de discussões sobre políticas governamentais, desenvolvimento social e eqüidade. A política editorial de $C S P$, ancorada no princípio de revisão por pares (peer review), está continuamente sendo aperfeiçoada com o objetivo de garantir a publicação de artigos criteriosamente revisados e recomendados por especialistas.

Publicado trimestralmente desde 1985, CSP tem se renovado a cada ano visando atender uma diversificada e exigente clientela de pesquisadores e de profissionais da área da saúde. O amplo espectro de tópicos abarcados pela revista atesta o esforço desta em contemplar, em face do perfil de seu público, um número crescente de temas, linhas de investigação e abordagens teórico-metodológicas na pesquisa em saúde pública.

A cada ano tem crescido o número de artigos recebidos e publicados. Por exemplo, entre 1996 (com 186 trabalhos recebidos e 83 publicados) e 1999 (com 250 originais recebidos até novembro e 109 publicados), verificou-se um aumento da ordem de $34 \%$ em trabalhos recebidos e $31 \%$ em artigos efetivamente publicados. Por razões de ordem operacional, optou-se por manter a periodicidade trimestral da revista. No entanto, para acomodar o maior número de artigos, o número total de páginas anuais experimentou expressivo aumento no período, de 578 em 1996 a 926 em 1999. A publicação de dois a três suplementos temáticos ao ano também tem encontrado excelente acolhida junto à comunidade científica, razão pela qual encontra-se em estudo uma estratégia para viabilizar o aumento no número de suplementos publicados ao ano. No que se refere às seções constituintes da revista, manteremos a prioridade para a publicação de artigos de pesquisa. Nos próximos anos, procuraremos, contudo, ampliar o espaço destinado a artigos de revisão e debates. Em relação à seção Debate, que foi uma inovação em saúde introduzida na literatura brasileira por $C S P$, vale mencionar que vem se consolidando como um fórum privilegiado para estimular discussões sobre temáticas atuais e polêmicas nos diferentes campos da saúde pública.

O novo milênio que está por vir constitui-se numa representação sócio-cultural e histórica de cronologias segundo algumas tradições ocidentais. Vive-se um momento de intenso revisionismo, particularmente oportuno para reflexões acerca de "mudanças" e "transições" em diferentes esferas. Para o campo da saúde pública, esses conceitos assumem especial importância. Eqüidade, envelhecimento da população, doenças emergentes e a persistência de "velhas" endemias são apenas alguns desafios, dentre muitos outros, que surgem ou que se renovam. Para fazer frente às antigas demandas que se perpetuam, assim como às novas questões que se impõem, Cadernos de Saúde Pública reitera seu compromisso com a disseminação de informação científica em saúde de qualidade, capaz de subsidiar o planejamento estratégico, o desenho de políticas, o diagnóstico de situações e a avaliação de serviços e de programas na eterna busca de melhores condições de vida e de saúde das populações.

Luis David Castiel e Carlos E. A. Coimbra Jr.

Editores 


\section{Cadernos de Saúde Pública (Reports in Public Health): On the eve of the year 2000}

This issue of Cadernos de Saúde Pública (CSP) marks the journal's 15th anniversary, reason for collective celebration with all those who have participated in this effort over the course of the years - authors, readers, consultants, and other collaborators. Such a milestone is certainly cause for great satisfaction on our part. We also see the 15th anniversary of CSP as a key moment to pause and reflect, as well to plan for the future. We are well aware of the many challenges involved in the quest for a scientifically consistent journal, with high editorial quality and expanding circulation.

Stemming from the research tradition launched at Manguinhos one hundred years ago, when the Oswaldo Cruz Institute was founded, CSP has become as a prime space for recording and disseminating state-of-the-art public health research from Brazil and Latin America as a whole, as well as other regions of the world where public health is part of the agenda for debate on public policies, social development, and equity. The editorial policy at CSP, rooted in the peer review principle, is constantly being improved with the goal of publishing articles that are carefully reviewed and recommended by specialists.

Published quarterly since 1985, CSP has renewed its approach every year to serve a diverse and demanding community of health researchers and professionals. To serve the needs of its reader public, the wide range of topics encompassed by CSP bears witness to the journal's efforts to cover an increasing number of public health research themes, lines of research, and theoretical and methodological approaches.

The number of articles received and published has grown year by year. For example, from 1996 (with 186 papers received and 83 published) to 1999 (with 250 originals received and 109 published), there was an increase of $34 \%$ in articles received and $31 \%$ in articles actually published. For operational reasons, we opted to continue publishing the journal on a quarterly basis. However, in order to accommodate the larger number of articles, the total number of pages per year underwent a major increase, from 578 in 1996 to 926 in 1999. The two to three special thematic editions published per year have also been very well received by the scientific community, thus spawning our current strategic plan to increase the number of special supplements published per year. In terms of the journal's various sections, publication of research articles will continue to be the priority. In coming years we will attempt to expand the space devoted to review and debate articles. The "debate" section was a concept first introduced into the Brazilian public health literature by $C S P$, and it has become a prime forum for stimulating discussion on current and controversial issues in our field.

The new millennium is a socio-cultural and historical representation of chronologies according to given Western traditions. We are experiencing a moment of intense revisionism that is especially timely for reflections on "changes" and "transitions" in different spheres. Such concepts are especially crucial for the field of public health. Equity, population aging or "graying", emerging diseases, and the persistence of old endemics are just a few of the many emerging and resurgent challenges. To tackle both the old, persistent demands and emerging issues, Cadernos de Saúde Pública reiterates its commitment to disseminate scientific information in high-quality health, capable of backing strategic planning, policy-making, diagnosis of situations, and evaluations of services and programs in the constant quest for better living and health conditions for the people. 